\title{
Government Publications
}

A subcommittee of the A.L.A. Public Documents Committee has been made reA-sponsible for a section in College and Research Libraries which is devoted to various phases of work with government publications.

It is intended that the scope of the contributions which appear in the section shall include annotated lists of bibliographical aids, subject lists of public documents, and notes of general interest to persons engaged in work in this field.

The committee: Violet Abbott Cabeen, chairman, James B. Childs, Mary Brown Humphrey, Robert E. Scudder.

By GRACE A. CAMPBELL .

\section{British Government Documents: A Guide to Their Use}

British official publications form a convenient and unequalled source of factual information on current political, economic, and social developments in the British Empire, owing to their wide range, good technical production, and authoritative chapeter. pribcipal or sele source of information on parieular subjects.

H. B. IleestSmith in his monograph entatted $A$ Guide to Parliamentary and Afficial Papens groups these publications as falings: 1

I. $P$ an

7. Fifationery Office Publications (Since I -24 cilled Non-Parliamentary Pub[i. ations].

3. statutou Rules and Orders.

4. Farliagarntary Debates.

5. Papers]Dealing with the Day-to-Day Proceed Ings of Parliament.

6. The Bund Volumes of This Last Group of Papers Issued to Form a Permanent Record.

7. Journals of Parliament.

d. 1 rest-Smith H. B. A Guide to Parliamentary and thiscials Inpers. Oxford University Press, I924 D. 5. Stominon School of Economics and Political scien asy in Economic and Political Science. Biblto and No. 5 ).

SEP'EMBER, 1941
To these might be added an eighth classification, Acts of Parliament.

The major portion of the documents are published by His Majesty's Stationery Office. This office is also charged with their distribution and sale. Established at the latter end of the eighteenth century as a government stationer's office, its functions are similar in many respects to those of the United States Government Printing Office and of the Superintendent of Documents.

The following current official lists are issued by the Stationery Office:

Great Britain. Stationery Office. Government Publications. 1936 to date.

Issued monthly (with a subject index through May, 1940). Includes Parliamentary and Non-Parliamentary Publications. Replaces Monthly List of Publications and Monthly Circular Divided as follows: first, Descriptive Notes on Chief Publications of the Month; second, Catalog of Publications Issued during the Month. The latter is divided into: first, Parliamentary Publications; second, Non-Parliamentary Publications (the departments are arranged alphabetically by the significant words in the 
name of the government authors); third, Periodicals which appear regularly once a month or oftener; fourth, Reissues; fifth, Miscellaneous Publications, such as those of the British Museum. Beginning with 1940, the Reissue section has not appeared, and the Miscellaneous Publications section has appeared only occasionally.

Great Britain. Stationery Office. Consolidated List of Government Publications. 1922 to date.

Issued annually at the end of the year. Based on Government Publications listed above. Includes Parliamentary and NonPtrliamentary Publications. Is the only cumulative list including Non-Parliamentary Publications. Preceded by the following publications: Quarterly List of Official and Parliamentary Publications, March I8941896. ${ }^{2}$ Quarterly List of Official Publications, 1897-1921. ${ }^{3}$ Quarterly List of Parliamentary Publications, I897-1921.4 Consolidated List of Government Publications issued annually and semiannually I92235 as the 6th and i2th number of each year of the Monthly List of Publications. Divided into Parliamentary, Non-Parliamentary, and Miscellaneous sections with a general alphabetical subject index. Gives for each publication listed (as does Government Publications) : title, document number, net price, and price with postage. Useful as a buying guide for current government material and as a subject index for publications of a given year. For Sessional Papers of the House of Commons it is superseded as an index by the annual Numerical List and Index to Printed Sessional Papers.

These two lists correspond in a general way to the United States Government Publications Monthly Catalog, with its annual index. The British list had the advantage of an index to the monthly issues through May 1940, when it was discontinued owing to the pressure of the

${ }^{2}$ Childs, J. B. An Account of Government Document Bibliography in the United States and Elsewhere. U.S. Government Printing Office, I930, p. ${ }_{42}$. [With revised dates. - S.B.C.]

3 Ibid. [With revised dates.-S.B.C.]
${ }^{4}$ Ibid. [With revised dates.-S.B.C.] war situation in Great Britain. Departmental and subject lists of Non-Parliamentary Publications are also available from the Stationery Office. They are comparable to the Price Lists issued by the United States Superintendent of Documents Office. Outstanding examples of the British lists are those issued by the Home Office, the Foreign Office, the Department of Scientific and Industrial Research, the Public Record Office (List $Q$ ), the Admiralty, and the Air Ministry. However, the publication of these lists has been discontinued for the duration of the war.

There are general indexes to Parliamentary Publications, each covering a period of years, but there are no indexes to Non-Parliamentary Publications for like periods. There is no British publication corresponding to the United States Document Catalog, which forms a permanent record of both Congressional and departmental publications since 1893 . The need of such a catalog for British publications was not felt untir the time of the first World War, because of the fact that so large a proportion of these documents had been included previously in the Parliamentary Publications and were thus covered by the general indexes to the latter.

Although Non-Parliamentary Papers have been issued for many years, no permanent lists exist previous to I894. The lack of permanent inclusive indexes to Non-Parliamentary Papers is a handicap to the user of British government documents.

\section{Parliamentary Publications}

Parliamentary Papers are all those papers presented to Parliament ordered to be laid on the table of the House, and recordec: and indexed in the Journals. Some of thes: re- 
main unprinted. Those in circulation as printed papers consist of the papers, other than the Votes and Proceedings, and the Journal, ordered to be printed by either of the Houses and of printed papers laid before the Houses by Royal Command and incorporated by them in their collections of sessional papers. ${ }^{5}$

Parliamentary Papers are numbered in a distinctive way according to the class of documents to which they belong. The numbers appear at the bottom left-hand corner of the title page. House of Lords Papers and Bills are numbered in one sequence and the number is inclosed in curved brackets. House of Commons Reports and Papers form one sequence and the numbers appear without brackets. House of Commons Bills have the word "Bill" prefixed to the number and the whole inclosed in square brackets. The above series are numbered afresh at each session of Parliament. Command Papers are numbered consecutively, theoretically up to 9999 , when they start afresh with number one and a prefix. The number was inclosed in square brackets up to 1923. It is still so inclosed in the $N u$ merical List and Index. The numbers of Parliamentary Papers at present appear thus:

House of Lords Papers and Bills. (5)

House of Commons Reports and $\mathrm{Pa}$ pers. 5

House of Commons Bills. [Bill 5]

Command Papers. Cmd. 5469

The House of Commons arranges its sessional papers for binding in a different fashion from that in which they first appear. They are arranged thus:

I. Public Bills.

2. Reports from Committees, Standing

${ }^{5}$ Bellot, H. H. "Parliamentary Printing, $1660-$ I 837." (In London. University. Institute of Historical Research. Bulletin II:92, 1933-34.

SEPTEMBER, 1941 and Select of House of Commons and Joint Committees of Both Houses.

3. Reports from Commissioners, Reports from Royal Commissions and Similar Bodies.

4. Accounts and Papers.

Private bills printed at the expense of the proposer are available only from these private sources and are not collected in the sessional papers. Inside the four groups listed above, the arrangement is alphabetical by subject. A general alphabetical index entitled, Numerical List and Index to Printed Sessional Papers, is published for each session. ' As a companion to this index there is published also sessionally Titles and Contents to the Sessional Papers. This includes a title page and index to each volume. $P$ Sheets are supplied showing the requisite lettering for the back of each volume when bound. A reference to both the unbound publication and to the bound publication should read, for House of Commons $R e$ ports and Papers: H.C. 90, p.2 ( 1887 ) XXXIX, $5 \mathrm{I} 7$; and for Command Papers after the period I833: Cd. I5IO, p.83, H.C. (1903) XX, $573 .^{6}$

The House of Lords papers are arranged similarly. - To avoid duplication the practice has been followed since 1900 of binding the Command Papers only in the House of Commons Sessional Papers. A Table and Index for the House of Lords papers was issued for each session up through 1920 , but for I92I to date there is only a general table of contents in the first volume of each session.

The British Sessional Papers have many points in common with the Serial Set of the United States Congressional documents. The arrangement of the Sessional Papers is more logical than that of the

Ibid., p. 97-98. 
Serial Set. United States Senate and House documents and reports, although printed in separate volumes, are combined in one numbered (serial) set with a numerical list and schedule of volumes published for each session.

Colors have been used to distinguish types of British Parliamentary documents.

While the Parliamentary Papers, particularly the series of bound sessional volumes, are generally though not universally known as Blue Books, only a small proportion of them today are issued in blue covers. All the smaller documents are issued without covers and the title page is printed on the same paper used for the text; such documents are known consequently as White $\mathrm{Pa}$ pers. Individual documents, then, may be either Blue Books, or White Papers according to their outward appearance. ... ${ }^{7}$

\section{Command Papers}

The Command Papers form the largest single class of annual Parliamentary

- Papers.V These include papers which do not actually originate in the House- They are presented to the House nominally by royal command. Included here, among other things, are reports of the older or more important government departments, important royal commissions, and noteworthy statements of government policy.l The series have been issued thus:

First series 18 I 8 -

$$
1832
$$

\section{Not scheduled}

Second series 1833 I 868-69

Third series $1870-$

$$
\text { I } 899
$$

Fourth series 1900I9I 8

$$
\text { [I]-[4222] }
$$

\section{[C.I]-[C.9550]}

\section{[Cd.I]-[Cd.9239]}

Fifth series 1919date

\section{[Cmd.I]-date ${ }^{8}$}

7Dalgoutte, W. C “'Blue Book' and 'White Paper." Special Libraries 30:333, Dec. I939. ${ }^{8}$ Horrocks, Sidney. "Government Publications."
Library Association Record 8:96, June I930 (new series).
Some of the annuals in this class have been issued for many years. Among these are the Statistical Abstract for the British Empire and the Statistical Abstract for the United Kingdom. These abstracts supply for the British nation information similar to that furnished by the United States government in its Statistical $A b$ stract.

\section{Reports of Committees and Commissions}

Although the reports of the various Parliamentary committees and commissions are published in the Parliamentary Papers, the minutes of evidence and appendices are sometimes published as NonParliamentary Papers.- This fact should not confuse one accustomed to using United States documents since the hearings, on which reports published in the Congressional set are based, are very rarely published in the Congressional series. Royal commissions are appointed by the Crown, sometimes at its own discretion and sometimes on the advice or demand of one or both Houses. They differ from the select committees of either House which are appointed from the House naming the committee, and the departmental committees which are selected from the departments with an occasional outsider included. Another type of committee which is of interest, is the department advisory committee, which has grown increasingly common since 191 $8 .^{\circ}$

Royal commissions have played an important part in the government of Great Britain.. The first one was appointed in I 386. Quite often the report of the commission is known by the name of the chairman, /a fact which is often a source

${ }^{9}$ Fairlie, J. F. "Advisory Committees in British Administration." American Political Science Revieze 22:81 2-22, Nov. 1926. 
of considerable confusion to users of these reports. For instance, the report of the Indian Statutory Commission is known as the Simon Report from the name of its chairman, Sir John Simon. ${ }^{10}$ Royal commissions are independent except for the control of the Treasury over their expenses. Sidney Webb says of them,

$\ldots$ They are frequently set up as a safety valve, or a channel for current agitations and counter agitations so as to enable the government, Parliament, and public opinion to test the value of, and to estimate the force behind, each of these agitations. From the standpoint of democratic control, and the education of public opinion, the British royal commission or committee of enquiry is the analogue of the American practice of public hearings. ... ${ }^{11}$

An example of a similar body in the United States is the recent U.S. Temporary National Economic Committee. A useful finding list of royal commission reports has been compiled by $\mathrm{A}$. H. Cole. ${ }^{12}$

\section{Official and Nonofficial Indexes to the Lords and Commons Papers}

The House of Commons Papers were printed as far back as I64I. $\checkmark$ From I8OI to 1835 some of them were included in the appendix to the Journals, where they could be examined by the public, but they were not put on sale until I835. The House of Lords Papers were sold beginning with I854. The Sessional Papers as such date back to about I 800. Collections of Parliamentary Papers date back to I 73 I, but only since the beginning of the nineteenth century have entire sets been

10 Fletcher, A. S. "Popular Names of zoth Century British Government Report." (In American Library Association. Committee on Public Docu ments. Public Documents, I937, p. 89-90, 132-217.) ${ }_{11}$ Webb, Sidney, and Webb, Beatrice. "Royal Commissions and Committees of Inquiry as Sources for the Investigator." (In their Methods of Social Study. Longmans, I932, p. I 5.)

12 Cole, A. H. A Finding-List of British Royal Commission Reports: 1860 to 1935 . Harvard University Press, 1935. preserved. ${ }^{13}$ Catalogs of the House of Commons Papers have been prepared covering the period I75I to $\mathrm{I} 800$, and of the Reports from 1696 to I 834 . A compilation of the reports from committees of the House and an index to them has been printed by order of the House.L

Great Britain. Parliament. House of Commons. Reports from Committees of the House of Commons, [1715-1801] [London] $1803-05.15 \mathrm{v}$.

Great Britain. Parliament. House of Commons. A General Index to the Reports from Committees, [1715-180I] [London] I 803 .

Besides annual indexes to the House of Commons Papers and the House of Lords Papers, there are also some general indexes, each covering a period of time, which facilitates the search for information. $\checkmark$

Great Britain. Parliament. House of Commons. General Alphabetical Index to the Bills, Reports, Estimates, Accounts, Printed by Order of the House of Commons and to the Papers Presented by Command, I80I-1929. London, H.M. Stationery Office, I 853-I93I.

The volumes are not numbered.

Contents: [v. I] General Index to Accounts and Papers, Reports of Commissions, etc., I80I-52; [v. 2] General Index to Bills, 1801-52; [v. 3] General Index to Reports of Select Committees, I8oI-52 ; [v. 4] General Index, 1852-99; [v. 5] General Index, 1900-09; [v. 6] General Index, 1910-19; [v. 7] $1920-28 / 29 .{ }^{14}$

The index 1852-99 through a serious error omits the sessional and command numbers of the documents. This series is continued by the annual index to the Sessional Papers. $\checkmark$

${ }^{13}$ Gaselee, Sir Stephen. "Libraries and Sources of Information in Government Departments." (In Association of Special Libraries and Information Bureaux. Proceedings of the I2th Conference, I935, p. 56 .)

${ }^{14}$ Mudge, I. G. Guide to Reference Books. 6th ed. American Library Association, 1936, p. 37 I. 
Great Britain. Parliament. House of Lords. General Index to Sessional Papers Printed by Order of the House of Lords or Presented by Special Command. London, Eyre, i 860-86. I 3 vols.

Contents: v. I. I $801-59$; v. 2. I859-70; v. 3. $\mathrm{I} 87 \mathrm{I}-85$.

From I 886-I920 the annual indexes must be used, 15

Since I92 I a table of contents has been published annually for the House of Lords Papers. In 1938 the Stationery Office reprinted the index volumes to the Papers of the Commons and the Lords covering the years $180 \mathrm{I}-52$ and $\mathrm{I} 8 \mathrm{O} I-59$ respectively.

A list of general and special indexes which cover Parliamentary and NonParliamentary Publications is to be found in the following compilation:

[Great Britain. Stationery Office.] Indexes and Bibliographical Publications of H.M. Stationery Office. [London, H.M. Stationery Office, I 939] $7 \mathrm{p}$.

A useful nonofficial index for Parliamentary Papers is:

King, firm, publishers, London. Catalogue of Parliamentary Papers, I80I-1920, with a Few of Earlier Date, compiled by Hilda Vernon Jones. London, King, 1904-22. 3 vols.

Contents: I801/I900. I904; I90I/IO. I912; $1911 / 20 . \quad 1922$.

\section{Non-Parliamentary Publications}

The non-Parliamentary group of documents includes among other things, the reports of smaller departments, the reports of department committees, and the minutes of evidence of royal commissions. ${ }^{16}$ The subjects with which these publications deal are many and varied. They include agriculture, art and science, national defense, economic and social questions, education,

15 Ibid.

16 Great Britain. Stationery Office. His Majesty's Stationery Office, I786-I925. [H.M. Stationery Office, $1925]$, p. 7. history and archeology, imperial and foreign affairs, medicine and public health, public administration, industry and technology, trade and commerce, transport and communications.

The tendency in recent years has been to transfer documents formerly issued as Parliamentary Papers to the NonParliamentary group. This has been done in response to demands for retrenchment. The following aids have been suggested to the searcher of public papers.

For a list of publications which were suspended, etc., by various government departments during the Great War, the reader is referred to the Report of the Select Committee on Publications and Debates' Reports, I916 (H.C. I12/1916), Appendix I; whilst for those which were transferred as the result of the postwar economy campaign the report of the same committee for 1923 (H.C. $140 /$ I $^{23}$ ) should be consulted. ${ }^{17}$

The John Crerar Library has prepared a list showing the transfers in the Sessional Papers from I9I 4 to $1933 .^{18}$ The prewar average total number of volumes of Sessional Papers at each session was approximately one hundred volumes; now it is about thirty. The Non-Parliamentary Publications have increased in volume correspondingly in the last twenty-five years. Among these are many publications which furnish the source material for the study of economic and social questions. A valuable series which provides an index to statistics contained in Parliamentary and Non-Parliamentary Publications is:

Great Britain. Permanent Consultative Committee on Official Statistics. Guide to the Current Official Statistics of the United Kingdom. 1922 to date.

Such an index is urgently needed for

17 Horrocks, op. cit., p. 98

18 Taylor, R. L. Guide to the Serial and Periodical Publications in Great Britain. Parliament. Sessional Papers, I914-1933. Preliminary ed., 1934. (John Crerar Library. Reference List No. 30.) 
United States government statistical publications.

\section{Statutory Rules and Orders}

The rules and regulations of general interest for any department are collected and published annually in the Statutory Rules and Orders, ". . . These regulations are made by government departments in the exercise of powers conferred upon them by some act of Parliament."19 They have the effect of law and are comparable to the regulations found in the United States Code of Federal Regulations. At present, two volumes a year are published. There is an index, issued triennially, to all Statutory Rules and Orders in force. The Statutory Rules and Orders issued before December 3I, I 903, and which were still in force on that date, have been published in a series of volumes known as the Revised Statutory Rules and Orders. A separate collection, not in Statutory Rules and Orders, entitled Manual of Emergency Legislation and containing war legislation for I914I 8 was published in five volumes.

\section{Parliamentary Debates}

The record of Parliamentary debates for the period before $\mathrm{I} 8 \mathrm{O} 3$ is covered by Cobbett's Parliamentary History of England from the Earliest Period to the Year I 803. This series, published by Hansard in thirty-six volumes, is a retrospective compilation rather than a current record..$^{20}$

The Parliamentary Debates proper begin in 1803 and are divided into five series:

(I) $\mathrm{I} 8 \mathrm{oo3}-20,4 \mathrm{I}$ vols.

(2) $1820-30,25$ vols.

(3) I 830-9I, 350 vols.

to Cowell, F. R. Bricf Guide to Government Publications. H.M. Stationery Office, 1938, p. 25. ${ }_{20}$ Mudge, op. cit., p. 130 .
(4) I 892-I 908, 77 vols.

(5) I 909 to the present date. ${ }^{21}$

There is an index for each volume and a general index for each year. The debates were privately reported up to I907, although the government gave financial aid beginning in 1855 . The verbatim reports began in 1909 , and since that date the debates of the two Houses have been published separately. The name of the early reporter and printer, Hansard, is often applied to the whole series. A supplementary series containing the debates in standing committees has been published since I9I9. The entire set is comparable to the United States Congressional Record and the publications which preceded it.

\section{Papers Dealing with the Day-to-Day Proceedings of Parliament}

The Blue Paper which is sent to the homes of the members every morning contains a record of the proceedings of Parliament, business to come before Parliament, questions for oral answer, and much general information. One of the principal sections of the Blue Paper is the Votes and Proceedings, which consists of a record of the decisions of the House of Commons on the previous day. It contains the information corresponding to that found in "History of Bills and Resolutions" in the United States Congressional Record. The House $V$ otes and Proceedings have been printed for sale to the public since 1680 . The White Paper is issued to members after they reach the House. It consists only of those parts of the Blue Paper which make up the agenda for the day. ${ }^{22}$ It is comparable to the Daily Calendar of the United States Congress.

${ }_{22}^{21}$ Lees.Smith, op. cit., p. 14. 22 Ibid., p. I6-19. 
The Blue Paper and White Paper are supplemented by four other documents which are furnished to members, namely, the Order Book of the House of Commons, the Weekly List of Public Bills, the list of Statutory Rules and Orders, and the Supply Lists, which show the account of the progress of the different Votes in Supply. ${ }^{23}$

\section{Bound Volumes of Day-to-Day Pro- ceedings of Parliament}

The bound volumes of these papers differ in arrangement from the plan on which they are issued to members. According to Lees-Smith the arrangement is as follows: (1) Votes, (2) Supplements to Votes, (3) Notices of Motion and Orders of the Day, (4) Public Bills, (5) Public Petitions, (6) Private Business, (7) Amendments to Private Bills, (8) Standing Committees, (9) Divisions. ${ }^{24}$ The Divisions correspond to the Yea and Nay Votes of the United States Congress. The House of Lords Minutes were printed beginning with 1824 but were not placed on sale until I 854 .

\section{Journals of Parliament}

The Journals are the official proceedings of both Houses.V The Journals of the House of Commons and the House of Lords were begun in their present form with the record for I 547 and 1509 respectively. They are printed for each session with an annual index at the end of each volume. The printing of the Journals (beginning with sixteenth century records) was first undertaken in the latter part of the eighteenth century. Gen-

\footnotetext{
${ }^{23}$ Ibid., p. I9.20.

24 Ibid., p. 20-21.
}

eral indexes issued in volumes covering periods of approximately ten years each are available for both series. The general indexes are very full and are often used instead of the Journals themselves. They contain a collection of precedents which are useful in the business of both Houses.

\section{Acts of Parliament}

Each act of Parliament is published separately first in the same manner as are the Slip Laws published by the United States Department of State. Local and private acts are issued only in separate leaflet form and must be bound by those collecting them. An annual bound volume entitled Public General Acts, containing the public acts, is issued. It is roughly comparable to the United States Statutes at Large. An annual publication of great importance is entitled Chronological Table and Index of the Statutes, in two volumes: (I) Chronological table of all statutes since 1235 with an indication of subsequent repealing acts, (2) Index to statutes in force./ For the complete set of statutes in force, the following is also needed:

Great Britain. Laws, statutes, etc., Statutes. $2 \mathrm{~d}$ ed. London, H.M. Stationery Office, I 888-1929. vols. I-24.

Covers the statutes I235-I920, arranged chronologically. Kept up to date by the annual volume of Public General Acts which have been published separately since I 886 .

For the period of the Interregnum the following compilation must be consulted:

Great Britain. Laws, statutes, etc. 16426o. (Interregnum.) Acts and Ordinances of the Interregnum, 1642-1660. Collected and edited by C. H. Firth and R. S. Rait for the Statute Law Committee. London, H.M. Stationery Office, I9I I. 3 vols. 